\title{
Synthesis of Niobium Carbides from Ferroniobium by Mechanochemical Method
}

\author{
Junya KANO, ${ }^{1)}$ SOLIHIN, ${ }^{1)}$ Nobuaki SATO, ${ }^{11}$ Shigeru SUZUKI, ${ }^{1)}$ Fumio SAITO, ${ }^{1)}$ Hidetaka SUGINOBE ${ }^{2)}$ and \\ Takahiro SHIOKAWA ${ }^{2)}$
}

1) Institute of Multidisciplinary Research for Advanced Materials, Tohoku University, 2-1-1, Katahira, Aoba-ku, Sendai $980-8577$

Japan. 2) Reseach Laboratories, JFE Mineral Company Ltd., 1 Niihama-cho, Chuo-ku, Chiba, 260-0826 Japan.

(Received on November 6, 2008; accepted on January 5, 2009)

\begin{abstract}
A feasible study on a novel production process of niobium carbide $(\mathrm{NbC})$ from its low cost resource ferroniobium at low temperature was examined by means of mechanochemical and subsequent chemical separation method. NbC powders as well as metallic iron (Fe) were synthesized from ferroniobium (FeNb) and graphite $(\mathrm{C})$ powders by using a planetary mill at milling speed of more than $600 \mathrm{rpm}$ with FeNb: $\mathrm{C}$ molar ratio of $1: 1$. Then $\mathrm{NbC}$ particles were effectively separated from the mixed powders by leaching with $\mathrm{HCl}$ after the heat-treatment of the mixed powders in argon. These experimental results were consistent with the thermodynamic prediction.
\end{abstract}

KEY WORDS: mechanochemical method; niobium carbide; ferroniobium; milling.

\section{Introduction}

Carbides of transition metals exhibit unique physical properties such as high melting point, good electrical conductivity and extremely high hardness. ${ }^{1)}$ These carbides are often used as materials for cutting tools, drills, and so on, because they have abrasive and wear resistance. In addition, the carbides are used as catalysts, such as for ammonia synthesis ${ }^{2)}$ and hydrogenation. ${ }^{3-5)}$ The transition metal carbides are industrially synthesized at high temperature either through solid-solid reaction or solid-liquid reaction, using various starting material such as elemental powder with carbon $^{6)}$ and oxide with methane gas. ${ }^{7)}$ However, the processing at high temperature generally requires energy, which is a critical disadvantage from economic and environmental points of view.

Powders of hard metal carbides are directly formed by reaction of refractory metals with carbon generally, but they may be synthesized in another route to reduce cost of raw materials and to save energy. For instance, ferroalloy containing refractory metals has been focused as one of the raw materials of refractory metals since the quantity of natural ores imported may be reduced by the ore supplying country. Typically, most of ferroniobium is produced from pyrochlore ore by aluminothermic reduction method in Brazil. Since the pyrochlore has advantages with its huge amount of resources and less amount of tantalum, it has become a main niobium resource for past decades. However, as it also contains a small amount of nuclear materials such as uranium and thorium, these materials should be separated from the ore and deposited at the mine. The ore powder is mixed with hematite as well as aluminum reducing agent forming ferroniobium (noted as FeNb hereafter). Therefore a new process in which the carbides of transition metals can be synthesized from ferroalloys at relatively lower temperature compared with the conventional process would be promising. In this paper, we have performed a feasible study on a novel production process of niobium carbide $(\mathrm{NbC})$ from ferroniobium $(\mathrm{FeNb})$ at low temperature by means of mechanochemical $^{8-10}$ and subsequent chemical separation method.

\section{Experimental}

Powders of commercial grade ferroniobium and graphite were used as starting materials, which were supplied from JFE Mineral Company and Wako Pure Chemicals Inc., respectively. They were mixed for the synthesis of niobium carbides by mechanochemical method without any purification. In this work, as-received sample of ferroniobium is noted as $\mathrm{Fe}-\mathrm{Nb}$. The mixing molar ratio of ferroniobium and graphite is 1 .

A laboratory scale planetary mill (P-7, Fritsch, Germany) equipped with vial and ball media made from stainless steel were used to conduct mechanochemical reaction. Vial height, vial diameter and ball diameter are 40, 40 and $16 \mathrm{~mm}$, respectively. $4.0 \mathrm{~g}$ of the mixture of ferroniobium and graphite was charged into the vial, and then the milling was conducted under argon atmosphere. The milling time was $120 \mathrm{~min}$. Rotational speed in the milling was in the range of 300-700 rpm, with an interval of $100 \mathrm{rpm}$. In order to avoid overheating during milling, milling was interrupted for $15 \mathrm{~min}$ for every milling for $15 \mathrm{~min}$.

The crystallographic phases in the sample powders were identified by X-ray diffractometer (Rigaku Rint2200/PC) with $\mathrm{Cu} \mathrm{K} \alpha$ irradiation at $40 \mathrm{kV} / 20 \mathrm{~mA}$ with Ni filter. The 


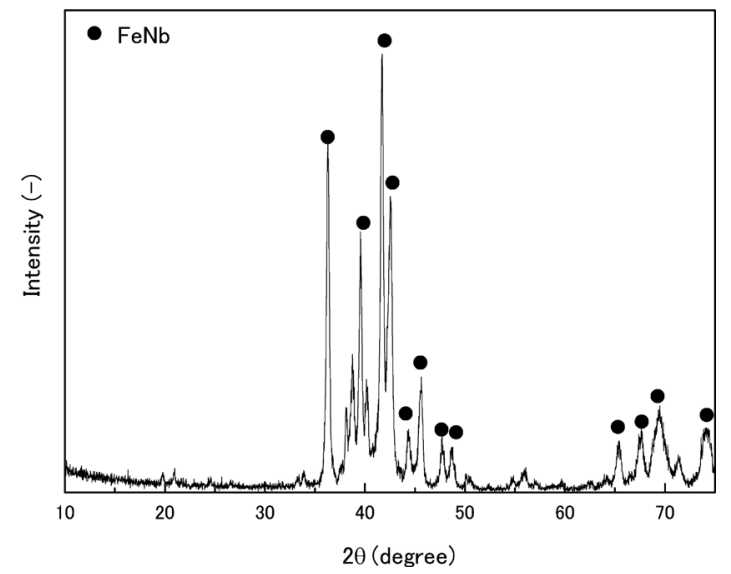

Fig. 1. XRD pattern of the as-received $\mathrm{Fe}-\mathrm{Nb}$ sample.

atomic composition of samples was determined by X-ray fluorescence analysis. The morphology of milled powder was observed by a scanning electron microscope (Hitachi $\mathrm{S}-2150$ ). The chemical composition of $\mathrm{FeNb}$ was analyzed using electron probe microanalysis (EPMA).

\section{Results and Discussion}

\subsection{Characterization of $\mathrm{Fe}-\mathrm{Nb}$}

Figure 1 shows an XRD pattern of as-received $\mathrm{Fe}-\mathrm{Nb}$. As the diffraction peaks primarily agree with those for $\mathrm{FeNb}$ given by solid marks, the sample is assigned to $\mathrm{Fe}_{7} \mathrm{Nb}_{6}{ }^{11)}$ Though commercial $\mathrm{Fe}-\mathrm{Nb}$ contains small amounts of impurity elements such as $\mathrm{Al}$ and $\mathrm{Si}$, compounds of these elements seem to be too low to be detected by the present XRD method.

EPMA was used for determine the microscopic composition of the Fe-Nb sample. Figures 2(a), 2(b) and 2(c) show secondary electron image, Fe characteristic X-ray image and $\mathrm{Nb}$ characteristic $\mathrm{X}$-ray image of the $\mathrm{Fe}-\mathrm{Nb}$ sample, respectively. Quantitative analyses for different points denoted in Fig. 2(a) were carried out, and the results are listed in Table 1. The results indicate that a few percent of impurity elements such as aluminum and silicon were distributed in the sample. The distribution of iron and niobium was fairly homogenized, although the amount of aluminum, silicon and titanium differs slightly in the sample.

\subsection{Synthesis of $\mathrm{NbC}$ from the Mixture of $\mathrm{Fe}-\mathrm{Nb}$ and C}

Figure 3 shows XRD patterns of the reaction product obtained by milling the mixture of $\mathrm{Fe}-\mathrm{Nb}$ and carbon powders at different rotation speeds. The molar ratio of $\mathrm{Fe}-\mathrm{Nb}$ and graphite mixed was 1 . The results showed that only diffraction peaks assigned to the $\mathrm{Fe}_{7} \mathrm{Nb}_{6}$ phase were observed in the products milled at low milling speed (300 and $400 \mathrm{rpm}$ ), but the diffraction peaks were broad, indicating that the grains are considerably decreased during milling. In general, as the energy of milling increases with an increasing of milling speed, ${ }^{12)}$ an increase in the milling speed the energy is like to induce to break or distort the bonds between atoms in the crystalline materials, which leads to the formation of poorly crystallized phase. The fraction of poorly crystallized gradually increases with increasing milling speed until the entire structure of the sample milled at

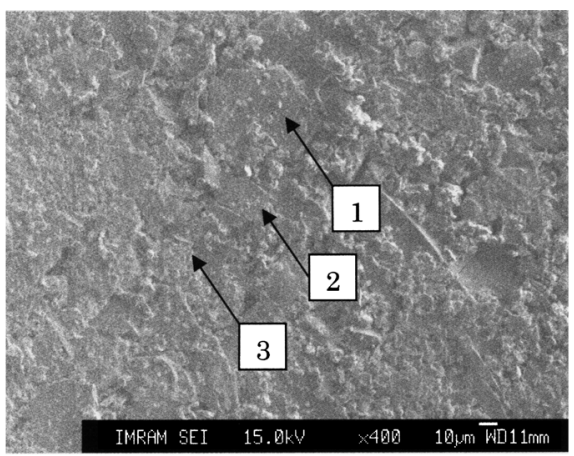

(a)

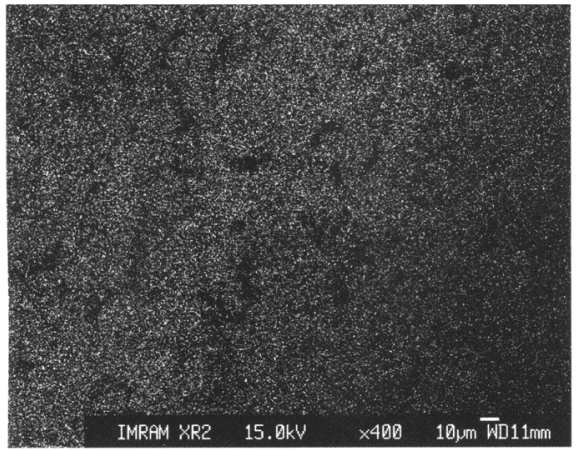

(b)

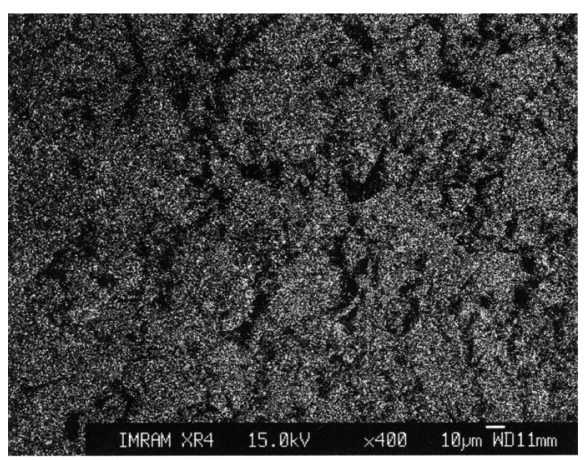

(c)

Fig. 2. (a) Secondary electron image, (b) Fe characteristic X-ray image and (c) $\mathrm{Nb}$ characteristic X-ray image of the as-received $\mathrm{Fe}-\mathrm{Nb}$ sample.

Table 1. Chemical composition determined by EMPA at the three points shown in Fig. 2.

\begin{tabular}{cccc}
\hline \multirow{2}{*}{ Element } & \multicolumn{3}{c}{ Atom \% } \\
\cline { 2 - 4 } & Point 1 & Point 2 & Point 3 \\
\hline $\mathrm{Fe}$ & 43.91 & 47.74 & 37.70 \\
\hline $\mathrm{Nb}$ & 40.51 & 39.92 & 30.80 \\
\hline $\mathrm{Si}$ & 5.00 & 6.47 & 2.19 \\
\hline $\mathrm{Al}$ & 4.19 & 0.57 & 2.00 \\
\hline $\mathrm{Ti}$ & 0.78 & 0.29 & 0.67 \\
\hline $\mathrm{O}$ & 5.59 & 3.45 & 23.9 \\
\hline
\end{tabular}

$500 \mathrm{rpm}$ seemed to be amorphous. Since the atomic bonds between $\mathrm{Fe}$ and $\mathrm{Nb}$ atoms were significantly distorted under such conditions, both $\mathrm{Fe}$ and $\mathrm{Nb}$ atoms may be so active to directly react with carbon atoms at milling speed more than 


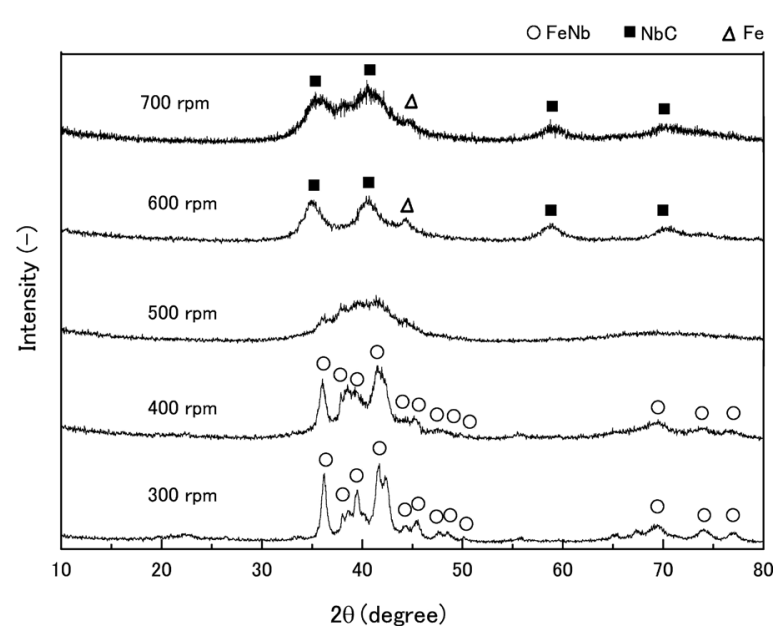

Fig. 3. XRD patterns of the mixtures of $\mathrm{Fe}-\mathrm{Nb}$ and graphite milled for $120 \mathrm{~min}$ at 300, 400, 500,600 and $700 \mathrm{rpm}$.

$500 \mathrm{rpm}$, by which breaking of the bonds between Fe and $\mathrm{Nb}$ atoms in the $\mathrm{Fe}-\mathrm{Nb}$ sample allows $\mathrm{Nb}$ atoms to form $\mathrm{NbC}$.

Actually, diffraction peaks assigned to $\mathrm{NbC}(\boldsymbol{\square})^{13)}$ together with small peaks assigned to metallic iron $(\triangle)$ phases were detected in XRD patterns of reaction products milled at 600 and $700 \mathrm{rpm}$, although diffraction peaks were broad. These results indicate that the formation of $\mathrm{NbC}$ from the mixture of FeNb and carbon critically occurs during mechanochemical process at high rotational speeds. As the reaction products are poorly-crystallized and very fine, some further heat treatment is necessary to separate $\mathrm{NbC}$ particles from the mixed phase.

\subsection{Separation of $\mathrm{NbC}$}

Reaction products obtained by milling $\mathrm{Fe}-\mathrm{Nb}$ and graphite at high milling speeds were heated in argon gas, to separate $\mathrm{NbC}$ and Fe. Since metal iron is known to be dissolved in an $\mathrm{HCl}$ solution, the samples heated were leached in dilute $\mathrm{HCl}$ solution at room temperature. XRD patterns of the products obtained by these processes were shown in Fig. 4. The sample shown in Fig. 4(a) is the mixture of $\mathrm{FeNb}$ and graphite powders with the $\mathrm{FeNb}: \mathrm{C}$ ratio of $1: 1$, which was milled by a planetary mill in argon atmosphere at $700 \mathrm{rpm}$ for $120 \mathrm{~min}$. An XRD pattern of the reaction products subsequently heated in $\mathrm{Ar}$ at $800^{\circ} \mathrm{C}$ for $2 \mathrm{~h}$ is given in Fig. 4(b). Diffraction peaks assigned to $\mathrm{NbC}$ and metal iron phases became sharp during heating, indicating that poorly-crystallized products were recrystallized by heat treatment. These results indicate that poorly-crystallized $\mathrm{NbC}$ and $\mathrm{Fe}$ powders are formed from $\mathrm{Fe}-\mathrm{Nb}$ and graphite by high speed milling, and the powders are well recrystallized by subsequent heating at about $800^{\circ} \mathrm{C}$ under inert atmosphere. Thus, the major mechanochemical reaction of $\mathrm{Fe}-\mathrm{Nb}$ with graphite can be written as follows:

$$
\mathrm{Fe}-\mathrm{Nb}+\mathrm{C} \rightarrow \mathrm{NbC}+\mathrm{Fe}
$$

This suggests that $\mathrm{FeNb}$ was decomposed to $\mathrm{NbC}$ and metallic Fe by mechanochemical reaction with carbon. It is noted that the reaction products still contain an amount of carbon in practical conditions.

Then, the separation of $\mathrm{NbC}$ from the mixture was conducted by leaching with dilute $\mathrm{HCl}$ solution at $60^{\circ} \mathrm{C}$ for $6 \mathrm{~h}$.

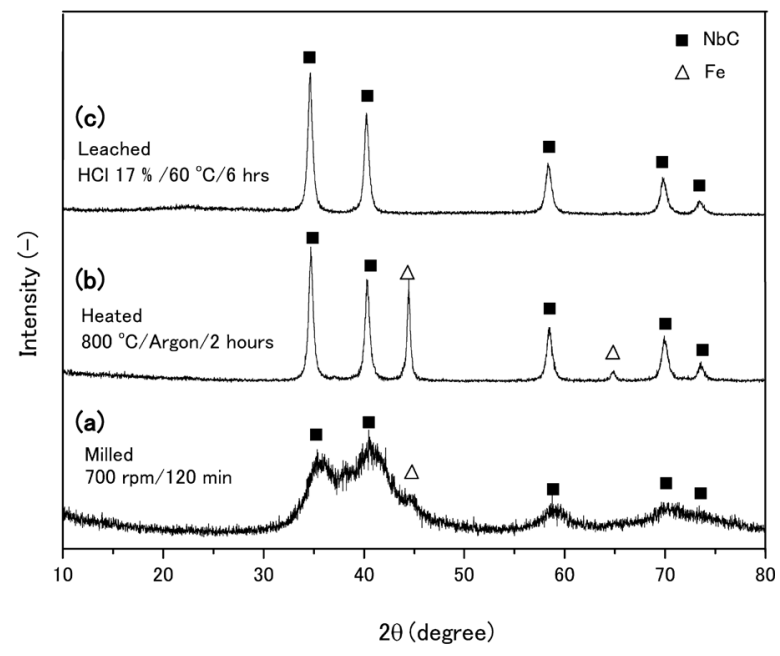

Fig. 4. XRD patterns of (a) the mixture of $\mathrm{Fe}-\mathrm{Nb}$ and graphite milled for $120 \mathrm{~min}$ at 300 , (b) the sample heated at $800^{\circ} \mathrm{C}$ under argon after milling, and (c) the sample subsequently leached in a $\mathrm{HCl}$ solution.

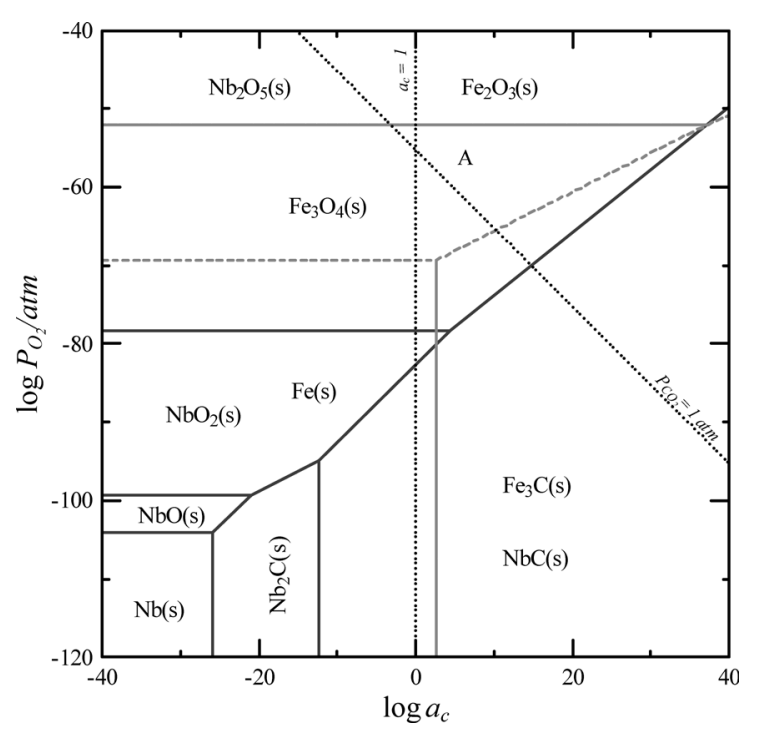

Fig. 5. Potential diagram for the $\mathrm{Nb}-\mathrm{O}-\mathrm{C}$ and $\mathrm{Fe}-\mathrm{O}-\mathrm{C}$ systems at $100^{\circ} \mathrm{C}$.

Figure 4(c) shows an XRD pattern of the product after leaching. Comparing with the XRD pattern for the heated sample shown in Fig. 4(b), it is seen that only the diffraction peaks for $\mathrm{NbC}$ are observed. This result suggests that $\mathrm{NbC}$ powder is separated by dissolution of metallic iron in the acid solution.

\subsection{Thermodynamic Consideration}

The formation of $\mathrm{NbC}$ from $\mathrm{FeNb}$ and graphite by mechanochemical method should be thermodynamically considered. The formation conditions were referred to the database "MALT for Windows". ${ }^{14)}$ If the reaction system is contaminated by residual oxygen, the mechanochemical reaction by oxygen may occur during the milling process. Therefore, the stability of relevant phases was considered by using oxygen potential and carbon potential. It is remarked that temperature of the surface of sample powders may rise by the collision with metallic ball. Figure 5 shows potential diagrams for the $\mathrm{Nb}-\mathrm{O}-\mathrm{C}$ and $\mathrm{Fe}-\mathrm{O}-\mathrm{C}$ systems at 


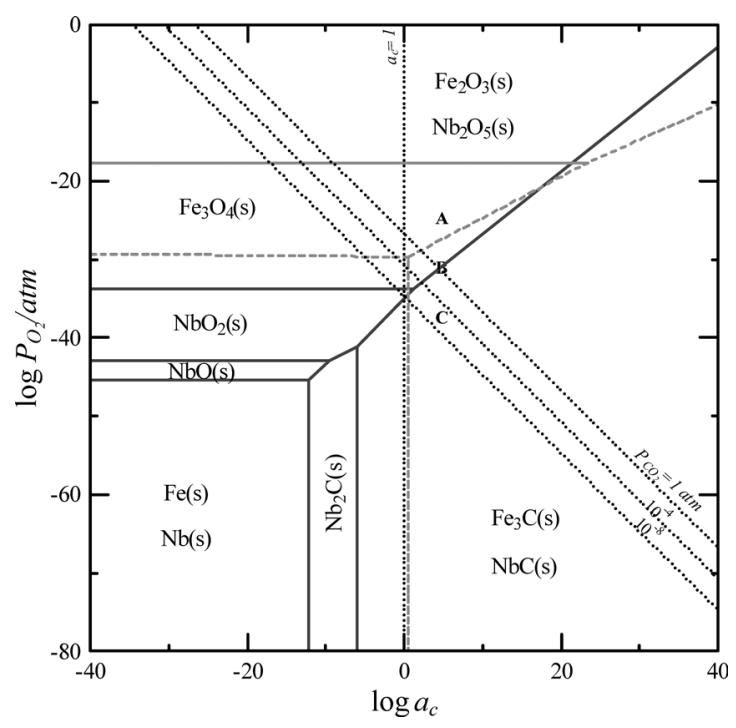

Fig. 6. Potential diagram for the $\mathrm{Nb}-\mathrm{O}-\mathrm{C}$ and $\mathrm{Fe}-\mathrm{O}-\mathrm{C}$ systems at $500^{\circ} \mathrm{C}$.

$100^{\circ} \mathrm{C}$. There are three stable niobium oxides, $\mathrm{NbO}, \mathrm{NbO}_{2}$, $\mathrm{Nb}_{2} \mathrm{O}_{5}$, and two iron oxides, $\mathrm{Fe}_{3} \mathrm{O}_{4}, \mathrm{Fe}_{2} \mathrm{O}_{3}$. Two niobium carbides, $\mathrm{Nb}_{2} \mathrm{C}, \mathrm{NbC}$ and cementite, $\mathrm{Fe}_{3} \mathrm{C}$ also exist in the diagrams. In both cases, no oxycarbide appears for the lack of thermodynamic data. Normally, the activity of solid carbon is unity. Under normal pressure, oxygen and carbon potentials should change according to the $P_{\mathrm{CO}_{2}}=1 \mathrm{~atm}$ line as given in the diagrams. The cross point $\mathrm{A}$ is located in the region of $\mathrm{Nb}_{2} \mathrm{O}_{5}$ and $\mathrm{Fe}_{3} \mathrm{O}_{4}$. If the $P_{\mathrm{CO}_{2}}$ decreases less, the point $\mathrm{A}$ does not come into the $\mathrm{NbC}$ and metallic iron region.

If the surface temperature of the sample may increases higher such as several hundred degrees, potential diagrams at higher temperatures are used to be discussed. Figure 6 shows potential diagrams for the $\mathrm{Nb}-\mathrm{O}-\mathrm{C}$ and $\mathrm{Fe}-\mathrm{O}-\mathrm{C}$ systems at $500^{\circ} \mathrm{C}$. Stable compounds of niobium and iron are the same as those at $100^{\circ} \mathrm{C}$. In the diagrams, the $P_{\mathrm{CO}_{2}}$ lines at $1,10^{-4}, 10^{-8} \mathrm{~atm}$ are given as dotted lines as well as the $a_{\mathrm{c}}=1$ line. At the cross point A where $P_{\mathrm{CO}_{2}}=1 \mathrm{~atm}$, stable products are $\mathrm{Nb}_{2} \mathrm{O}_{5}$ and $\mathrm{Fe}_{3} \mathrm{O}_{4}$ which are the same as those at $100^{\circ} \mathrm{C}$. However, the cross point $\mathrm{B}$, i.e. $P_{\mathrm{CO}_{2}}=10^{-4} \mathrm{~atm}$, they are the mixture of $\mathrm{Nb}_{2} \mathrm{O}_{5}$ and metallic iron. Furthermore, at $P_{\mathrm{CO}_{2}}=10^{-8}$ atm, the cross point $\mathrm{C}$ is very close to the region of $\mathrm{NbC}$. The product would be the mixture of $\mathrm{NbC}$ and metallic iron, even though the $\mathrm{CO}_{2}$ pressure seems to be too low.

Figure 7 shows potential diagrams for the $\mathrm{Nb}-\mathrm{O}-\mathrm{C}$ and $\mathrm{Fe}-\mathrm{O}-\mathrm{C}$ systems at $800^{\circ} \mathrm{C}$. In the diagrams, very small area of another iron oxide phase $\mathrm{FeO}$ appears between $\mathrm{Fe}$ and $\mathrm{Fe}_{3} \mathrm{O}_{4}$. The $\log a_{\mathrm{c}}$ line lies on the border line between $\mathrm{Fe}$ and $\mathrm{Fe}_{3} \mathrm{C}$. At $P_{\mathrm{CO}_{2}}=1 \mathrm{~atm}$, the cross point $\mathrm{A}$ is still in the region of $\mathrm{Nb}_{2} \mathrm{O}_{5}$. However, $P_{\mathrm{CO}_{2}}$ becomes lower than $10^{-4}$ atm (B, $\mathrm{C}$ ), formation of $\mathrm{NbC}$ as well as metal iron could be possible. Therefore, the present thermodynamic consideration is consistent with the experimental results obtained by the present work.

\subsection{Energy Required for Synthesis of $\mathrm{NbC}$}

In this paper a new and novel method to synthesis through mechanochemical route of $\mathrm{NbC}$ has been proposed.

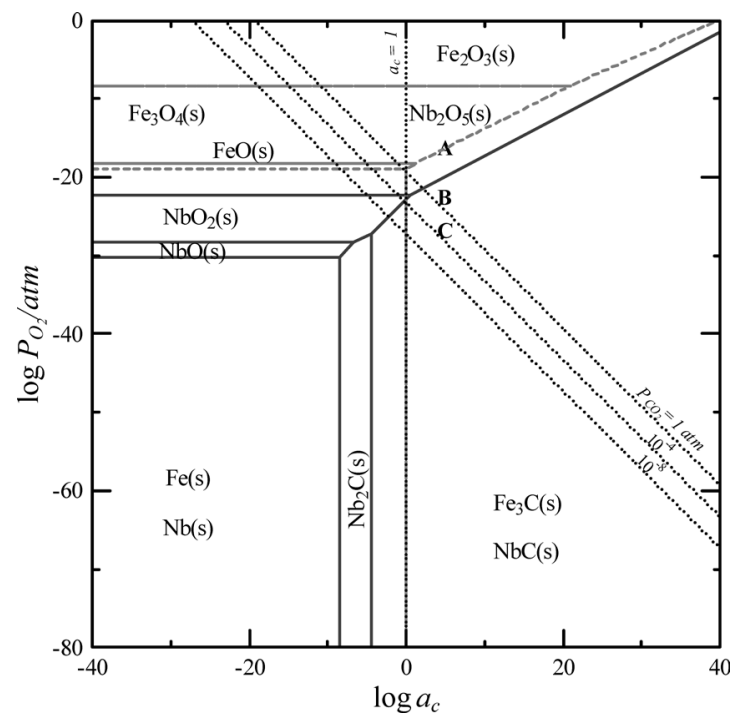

Fig. 7. Potential diagram for the $\mathrm{Nb}-\mathrm{O}-\mathrm{C}$ and $\mathrm{Fe}-\mathrm{O}-\mathrm{C}$ systems at $800^{\circ} \mathrm{C}$

The energy for synthesis of $\mathrm{NbC}$ from a mixture $\mathrm{FeNb}$ and carbon through mechanochemical route is calculated. The electric power consumption of the planetary ball mill used in this work is $570 \mathrm{~W}$ according to the specification. The planetary mills worked for $2 \mathrm{~h}$ to synthesize $\mathrm{NbC}$. Then the integral electric power consumption is $570 \mathrm{~W} \times 2 \mathrm{~h}=$ $1140 \mathrm{Wh}$. On the other hand, when using electric furnace to prepare $\mathrm{NbC}$ from the mixture $\mathrm{FeNb}$ and carbon, it usually requires $2800 \mathrm{~W}$ at least for keeping $1600^{\circ} \mathrm{C}$ as electric power consumption according to the general information of electric furnaces. ${ }^{15)}$ In general synthesizing time is $10 \mathrm{~h}$ at least. Then the integral electric power consumption is $28000 \mathrm{Wh}$. The method proposed in this paper is more effectively than the heating method.

\section{Conclusion}

The syntheses of $\mathrm{NbC}$ powders from ferroniobium and graphite powders by means of mechanochemical process at ambient temperature have been investigated. The reaction products were characterized by the X-ray diffraction method. The results showed that structurally distorted $\mathrm{NbC}$ powders were synthesized from ferroniobium and graphite powders by using a planetary mill at milling speed of more than $600 \mathrm{rpm}$. The $\mathrm{NbC}$ powders were heated under argon gas to be recrystallized. The $\mathrm{NbC}$ and Fe particles heated at high temperature were leached in the $\mathrm{HCl}$ solution to remove Fe particles. Finally, $\mathrm{NbC}$ particles were separated from the mixed powders. These experimental results were consistent with the thermodynamic prediction. As ferroniobium is relatively low cost resource containing niobium, the present process is likely to be promising to extract niobium.

\section{REFERENCES}

1) L. E. Toth: Transition Metal Carbides and Nitrides, Academic Press New York, (1971).

2) M. Boudart, S. T. Oyama and L. Lecreleq: Proc. of 7th Int. Cong. on Catalysis, Vol. 1, ed. by T. Seiyama and K. Tanabe, Elsevier, Amsterdam, (1981), 578.

3) I. Kojima, E. Miyazaki, Y. Inoue and I. Yasumori: J. Catal., 59 
ISIJ International, Vol. 49 (2009), No. 3

(1979), 473.

4) I. Kojima, E. Miyazaki, Y. Inoue and I. Yasumori: J. Catal., 73 (1982), 128.

5) B. Viddick, J. Lemaitre and L. Lecreleq: J. Catal., 99 (1986), 439.

6) T. Tsuchida and Y. Azuma: J. Mater. Chem., 7 (1997), 2265.

7) F. A. O. Fontes, K. K. P. Gomes, S. A. Oliviera, C. P. Souza and J. F. Rousa: Brazillian J. Chem. Eng., 21 (2004), 393.

8) W. Tongamp, J. Kano, Q. Zhang and F. Saito: Waste Management, 28 (2008), 484.

9) J. Kano, E. Kobayashi, W. Tongamp and F. Saito: Chemistry Letters, 37 (2008), 204
10) J. Kano, L Jenfeng, I. C. Kang, W. Tongamp, E. Kobayashi and F. Saito: Chemistry Letters, 36 (2007), 900.

11) Kripyakevich: Sov. Phys. Crystallogr., 12 (1968), 525

12) C. Suryanarayana: Prog. Mater. Sci., 46 (2001), No. 1-2, 1.

13) W. Wong-Ng, H. McMurdie, B. Paretzkin, C. Hubbard and A. Dragoo: Powder Diffr., 3 (1988), 55.

14) J. Soc. Calorimetry and Thermal Analysis, The MALT for Windows, Kagaku Gijutsu-Sha, Tokyo, Japan, (2004).

15) Handbook of Extractive Metallurgy, Vol. III, Chap. 28, ed. by F. Habashi, Wiley-Vch., Weinheim, Germany, (1997), 1410. 